Marine Biology 27, 173-184 (1974)

(C) by Springer-Verlag 1974

\title{
An Osteological Study of the Dugong Dugong dugon (Sirenia) from India
}

\author{
P.S.B.R. James \\ Central Marine Fisheries Research Institute; Cochin, India
}

\section{Abstract}

An osteological study of the dugong (sea cow) Dugong dugon (Miiller) from India, based on complete skeletons of an adult male and a juvenile female indicated certain morphological variations with age. It has also revealed a close osteological similarity between the dugongs from India and the Red Sea. Based on a statistical analysis, regression equations for certain typical skull measurements have been calculated; these equations, characteristic of the dugong from India, could be used for comparing dugongs of different regions.

\section{Introduction}

Opinions differ as to whether or not the dugong or sea cow Dugong dugon (Miiller) constitutes a single species throughout its entire range of distribution. Only fragmentary information is at present available from different localities due to the nonavailability, for study purposes, of adequate material of this comparatively rare and interesting animal. The dugong is often caught along the Palk Bay and the Gulf of Mannar coasts in the south-eastern region of India. A few reports on the occurrence and habits of Dugong dugon (Mü1ler) have been pub1ished earlier (Jones, 1959; Mani, 1960; Silas, 1961; Mohan, 1963), and much valuable information on its biology and behaviour has been provided by a pair of captive dugongs kept alive in the Aquarium of the Central Marine Fisheries Research Institute, Mandapam Camp (Jones, 1967). However, an osteological study of the dugong from the Indian region has so far not been reported. In order to compare the osteological characters of the dugong from this region with those of dugongs from other regions with a view to aiding in eventual clarification of the species problem, a detailed study of the dugong skeleton was made; the results are presented in this paper.

Earlier works on the skeletal features of the Sirenia in general or on dugongs from particular localities include those of Sedgwick (1905), Beddard (1902), Parker and Haswel1 (1940), Petit (1955) and Gohar (1957).
Material and Methods

The material examined in this study consists of two complete skeletons of an adult male $(275 \mathrm{~cm}$ long) and a young female (106 cm long; length measured from snout tip to tail fork) captured from the Gulf of Mannar. The male was caught near Hare Island $(9.4 \mathrm{~km}$ from Mandapam) on the $14 \mathrm{th}$ September, 1965 and the female at Valai Island $(21.7 \mathrm{~km}$ from Mandapam) on the 9 th December, 1965. In addition to the above, 12 skulls ranging from 262 to $384 \mathrm{~mm}$ in condylobasal length, several vertebrae and pectoral girdles collected from coastal areas of the Gulf of Mannar and the Palk Bay, and three skulls, 376 to $384 \mathrm{~mm}$ in condylobasal length, available at the Bombay Natural History Society, Bombay, were also studied.

The two complete dugong skeletons were prepared by removing the greater part of the flesh whilst still fresh; the bones were then placed in boiling water for about $3 \mathrm{~h}$ to soften adhering tissues, and finally cleaned and dried in the sun.

Fourteen morphometric measurements were taken from the skulls of seven males and 10 females (Table 1). A few (Specimens 1 to 14 , Table 1) were selected for further statistical analysis to determine possible sex differences.

The angle of deflection of the premaxillaries was determined by pressing a flexible wire on the dorsal surface of the skull to obtain the natural contour. Then, the wire was placed on a paper and a few points noted along its course. These were joined to give the angle of deflection of premaxillaries with reference to the dorsal surface of the skull (Table 1).

Osteology

SkuI1

The skull is massive, heavy, elongate and characteristically hard. The anterior third is very narrow and bent downwards at an angle ranging from $120^{\circ}$ to $136^{\circ}$ (Figs. 1 and 2). The premaxillaries are long, with their anterior portions deflected downwards (Figs. 1 and 2). The bent anterior portion of each premaxillary contains a large cavity, $12 \mathrm{~cm}$ long, $3.5 \mathrm{~cm}$ wide, which holds the 
$16.5 \mathrm{~cm}-1$ ong tusk. The exposed part of the tusk measured $4.5 \mathrm{~cm}$ in the large male specimen. The premaxillaries are separate. The posterior portions of the premaxillaries curve round, forming a large median cavity. At the posterior extremity they articulate with the lacrymals, which are small, flat bones. The frontals are fused into a single bone with two lateral, wing-like, anterior extensions. The paired nature of the frontals is indicated by a small median anterior suture. The

Table 1. Dugong dugon. Skull measurements

\begin{tabular}{|c|c|c|c|c|c|c|c|c|c|}
\hline $\begin{array}{l}\text { Skul1 } \\
\text { no. }\end{array}$ & $\begin{array}{l}\text { Condy } 10- \\
\text { basal } \\
\text { length } \\
(\mathrm{mm})\end{array}$ & $\begin{array}{l}\text { Palatal } \\
\text { length } \\
(\mathrm{mm})\end{array}$ & $\begin{array}{l}\text { Muzzle. } \\
\text { width } \\
\text { (mm) }\end{array}$ & $\begin{array}{l}\text { Interor- } \\
\text { bital } \\
\text { constric- } \\
\text { tion (mm) }\end{array}$ & $\begin{array}{l}\text { Postor- } \\
\text { bital } \\
\text { constric- } \\
\text { tion (mm) }\end{array}$ & $\begin{array}{l}\text { Zygo- } \\
\text { matic } \\
\text { width } \\
(\mathrm{mm})\end{array}$ & $\begin{array}{l}\text { Condyle } \\
\text { width } \\
(\mathrm{mm})\end{array}$ & $\begin{array}{l}\text { Exocci- } \\
\text { pital } \\
\text { width } \\
(\mathrm{mm})\end{array}$ & $\begin{array}{l}\text { Premaxil- } \\
\text { lary } \\
\text { length } \\
(\mathrm{mm})\end{array}$ \\
\hline 1 & 354 & 225 & 84 & 146 & 144 & 221 & 99 & 155 & 199 \\
\hline 2 & 153 & 90 & 27 & 74 & 76 & 122 & 48 & 89 & 83 \\
\hline 3 & 307 & 180 & 60 & 122 & 130 & 187 & broken & 136 & 156 \\
\hline 4 & 262 & 156 & 54 & 114 & 115 & 171 & 81 & 131 & 141 \\
\hline 5 & 355 & 238 & 78 & 164 & 160 & 234 & 97 & 149 & 199 \\
\hline 6 & 384 & 246 & 84 & 174 & 168 & 219 & 97 & 150 & 218 \\
\hline 7 & 324 & 210 & 74 & 133 & 138 & 203 & 92 & 152 & 190 \\
\hline 8 & 337 & 192 & 63 & 146 & 139 & 194 & broken & 146 & 186 \\
\hline 9 & 361 & 245 & 75 & 171 & 178 & 233 & 102 & 156 & 172 \\
\hline 10 & 337 & 218 & 74 & 150 & 151 & 212 & 102 & 151 & 187 \\
\hline 11 & 330 & 213 & 76 & 151 & 152 & 208 & 91 & 150 & 192 \\
\hline 12 & 365 & 231 & 78 & 157 & 156 & 225 & broken & 140 & 197 \\
\hline 13 & 295 & 176 & 53 & 133 & 124 & 182 & broken & broken & 148 \\
\hline 14 & 356 & 231 & 83 & 161 & 163 & 236 & 97 & 157 & 202 \\
\hline 15 & 376 & 220 & 75 & 162 & 156 & 221 & broken & broken & 195 \\
\hline 16 & 376 & 248 & 82 & 173 & 175 & 234 & 99 & 144 & 250 \\
\hline 17 & 384 & 217 & 81 & 145 & 150 & 210 & broken & broken & 196 \\
\hline
\end{tabular}


parietals are fused into a single, flat posteromedian bone. At the back of the skull, the foramen magnum is surrounded dorsally by the supraoccipital, laterally by the exoccipitals, ventrally by the basioccipital. The occipital condyles are prominent.
The upper margin of the supraoccipital is arched, and on its surface is a median ridge with two lateral depressions. The union of the exoccipitals and the basioccipital is complete. The zygomatic arch is formed by the large squamosal and the jugal

\begin{tabular}{|c|c|c|c|c|c|c|c|}
\hline $\begin{array}{l}\text { Lower } \\
\text { jaw } \\
\text { length } \\
\text { (mm) }\end{array}$ & $\begin{array}{l}\text { Mandible } \\
\text { Straight } \\
\text { part } \\
\text { (mm) }\end{array}$ & $\begin{array}{l}\text { length } \\
\text { Deflect- } \\
\text { ed part } \\
(\mathrm{mm})\end{array}$ & $\begin{array}{l}\text { Nasal } \\
\text { cavity } \\
\text { width } \\
(\mathrm{mm})\end{array}$ & $\begin{array}{l}\text { Premaxil- } \\
\text { lary } \\
\text { thick- } \\
\text { ness (mm) }\end{array}$ & $\begin{array}{l}\text { Angle of } \\
\text { deflec- } \\
\text { tion of } \\
\text { rostrum }\end{array}$ & Teeth $\mathrm{h}^{\mathrm{a}}$ & Sex \\
\hline 272 & 205 & 107 & 71 & 73 & $127^{\circ}$ & $\frac{1+3}{(1+4)+2}$ & Male \\
\hline 122 & 99 & 38 & 40 & 20 & $136^{\circ}$ & $\frac{2+3}{(1+3)+3}$ & Female \\
\hline 206 & 156 & 70 & 69 & 49 & $129.5^{\circ}$ & $\frac{2+4}{(1+3)+4}$ & Female \\
\hline $\begin{array}{l}\text { not } \\
\text { available }\end{array}$ & $\begin{array}{l}\text { not } \\
\text { available }\end{array}$ & $\begin{array}{l}\text { not } \\
\text { available }\end{array}$ & 55 & 37 & $124^{\circ}$ & $\frac{2+4}{\text { no lower jaw }}$ & Female \\
\hline $\begin{array}{l}\text { not } \\
\text { available }\end{array}$ & $\begin{array}{l}\text { not } \\
\text { available }\end{array}$ & $\begin{array}{l}\text { not } \\
\text { available }\end{array}$ & 72 & 61 & $125^{\circ}$ & $\frac{1+2}{\text { no lower jaw }}$ & Male \\
\hline 278 & 217 & 92 & 76 & 80 & $127^{\circ}$ & $\frac{1+3}{(1+3)+2}$ & Male \\
\hline 264 & 200 & 104 & 63 & 62 & $121^{\circ}$ & $\frac{1+3}{(1+3)+2}$ & Male \\
\hline 246 & 184 & 92 & 69 & 49 & $120^{\circ}$ & $\frac{2+4}{(1+3)+4}$ & Female \\
\hline $\begin{array}{l}\text { not } \\
\text { available }\end{array}$ & $\begin{array}{l}\text { not } \\
\text { available }\end{array}$ & $\begin{array}{l}\text { not } \\
\text { available }\end{array}$ & 73 & 60 & $121.5^{\circ}$ & $\frac{1+3}{\text { no lower jaw }}$ & Male \\
\hline $\begin{array}{l}\text { not } \\
\text { available }\end{array}$ & $\begin{array}{l}\text { not } \\
\text { avai } 1 a b l e\end{array}$ & $\begin{array}{l}\text { not } \\
\text { available }\end{array}$ & 78 & 56 & $124.5^{\circ}$ & $\frac{1+3}{\text { no lower jaw }}$ & Male \\
\hline 265 & 192 & 90 & 74 & 65 & $122^{\circ}$ & $\frac{1+2}{(1+3)+3}$ & Male \\
\hline 268 & 211 & 100 & 72 & 58 & $125.5^{\circ}$ & $\frac{1+3}{(1+3)+2}$ & Female \\
\hline $\begin{array}{l}\text { not } \\
\text { available }\end{array}$ & $\begin{array}{l}\text { not } \\
\text { available }\end{array}$ & $\begin{array}{l}\text { not } \\
\text { availab le }\end{array}$ & 68 & 43 & $134.5^{\circ}$ & $\frac{2+4}{\text { no lower jaw }}$ & Female \\
\hline 275 & 210 & 112 & 76 & 62 & $121^{\circ}$ & $\frac{1+2}{(1+3)+2}$ & Female \\
\hline 266 & 190 & 125 & 80 & 56 & no data & $\frac{1+5}{(1+3)+4}$ & Female \\
\hline 298 & 226 & 119 & 76 & 61 & no data & $\frac{1+2}{(1+3)+2}$ & Female \\
\hline 280 & 204 & 109 & 75 & 60 & no data & $\frac{1+3}{(1+3)+3}$ & Female \\
\hline
\end{tabular}

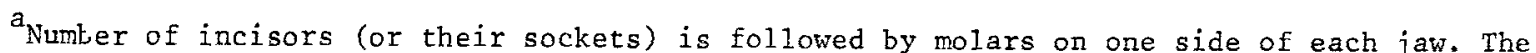
values in parentheses indicate, respectively, the number of anterior and posterior incisors (or their sockets) in lower $j a w$, on one side. Specimens 15 to 17 , from the Bombay Natural History Society, are presumed to come from northern region of Arabian Sea; 15 and 16 labelled M5971 and M5970, 17 dated 18.8.1959.
} 
bones. The bones can be separated easily at the point of articulation. The infraorbital foramen is formed by portions of the maxillary and the jugal, the latter bone constituting only a small portion of the anterolateral and posterolateral corners. The ventrolateral portion of the squamosal pro- vides, on each side, an articular surface for the condyloid process of the lower jaw. The maxillaries are large, and bear teeth posteriorly. On each side there are three teeth, the anteriormost smallest, the posteriormost largest and shoeshaped. The maxillaries articulate in front and
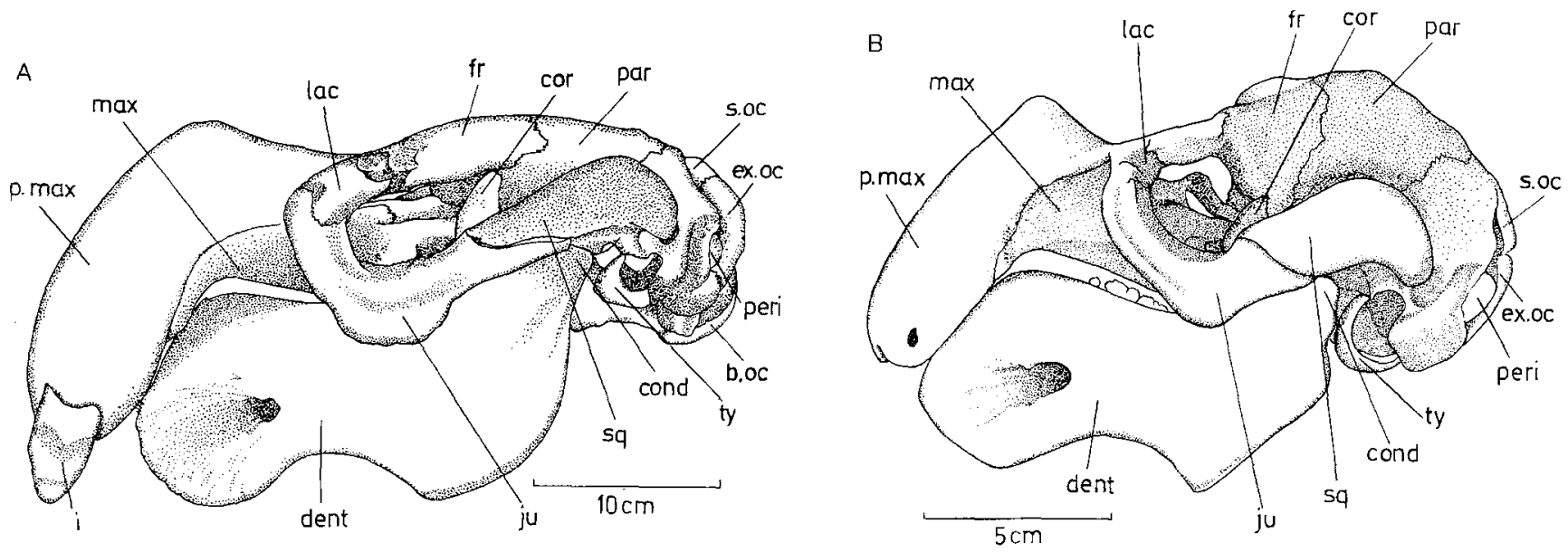

Fig. 1. Dugong augon. Lateral view of skull of (A) adult male, (B) juvenile female. b.oc: Basioccipital; cond: condyloid process of mandible; cor: coronoid process of mandible; dent: dentary; ex.oc: exoccipita1; fr: frontal; $i$ : incisor; ju: jugal; lac: lacrymal; max: maxillary; par: parietal; peri: periotic; p.max: premaxillary; s.oc: supraoccipital; sq: squamosal; ty: tympanic
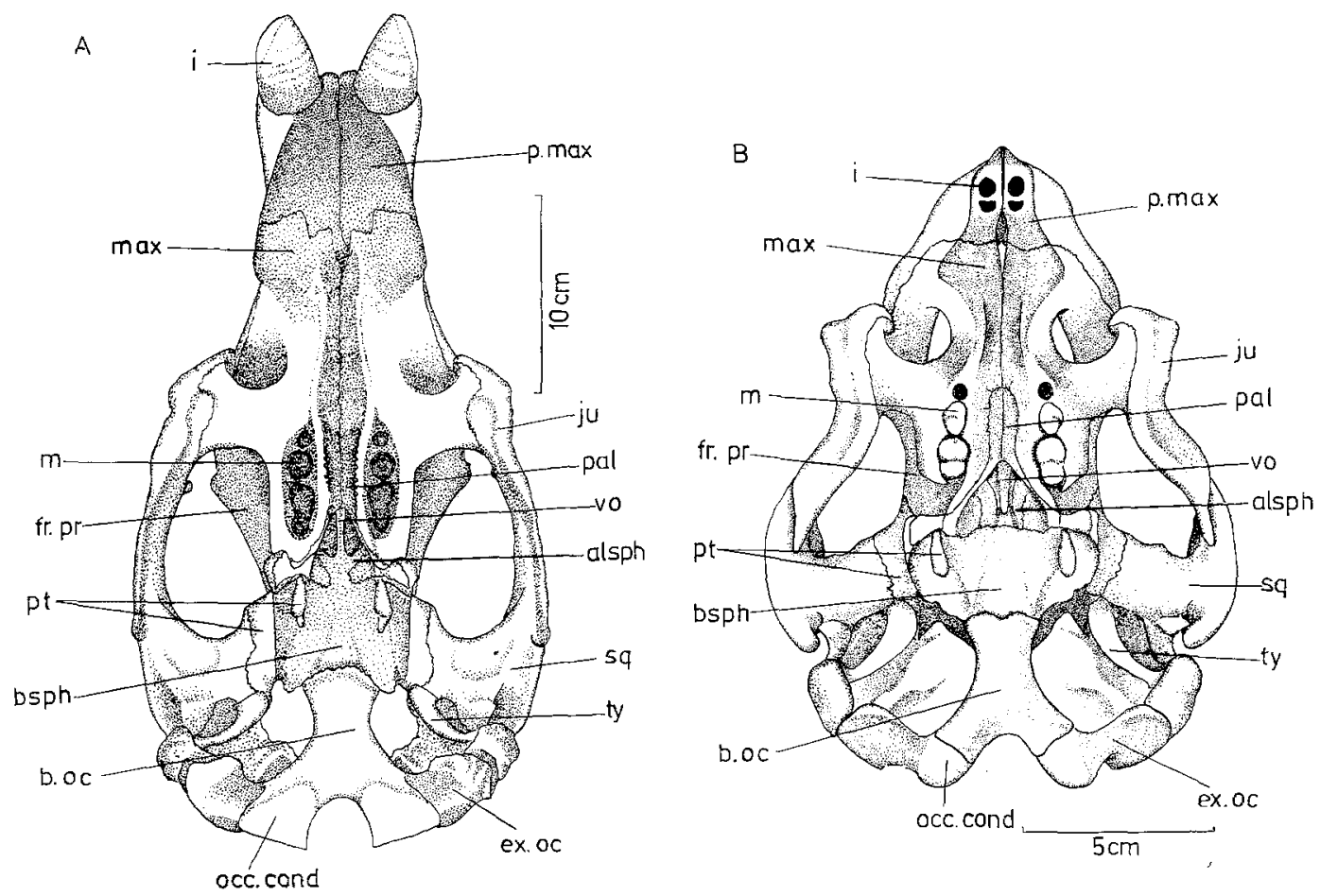

Fig. 2. Dugong dugon. Ventral view of neurocranium of (A) adult male, (B) juvenile female. alsph: Alisphenoid; bsph: basisphenoid; fr.pr: frontal process; m: molar tooth; occ.cond: occipital condyle; pal: palatine; pt: pterygoid; vo: vomer. Other abbreviations as in Fig. 1 
above with the premaxillaries, laterally with the jugals, posteriorly with the palatines. They also enclose a groove along the median line, in front of the teeth. The palatines are small bones, the anterior ends of which are horizontal. The anterior extremities of the palatines are at about the same level as the first pair of rudimentary teeth. The posterior portions of the palatines are vertical, and articulate with the basisphenoid. The sutures between the palatines themselves and between these and the jugals are very wavy. The basisphenoid articulates behind with the basioccipital; at their point of union, a bulbous projection is present in the posteroventral region of the skull. Distinct sutures are visible where the pterygoids unite with the palatines, but these are not seen where they unite with the basisphenoid. Each pterygoid bears a ventromedian process representing portions of alisphenoid, basisphenoid and palatine. The vomer is a narrow median bone articulating behind with the basisphenoid, below with the anterior ends of the palatines, and in front with the maxillaries. The nasals are absent. The alisphenoids are situated on either side of the base of the vomer. The sutures of union with the adjoining bones are indistinct.

The auditory capsule is formed by the massive periotic bone and the ring-like tympanic bone, the latter supporting the tympanic membrane. The tympanic cavity is open, with the auditory aperture situated below the posterior end of the zygomatic arch.
The lower jaw is formed on each side by the dentary, with prominent coronoid and condyloid processes posterodorsally, and an imperceptible angular process posteroventrally. The middle portion of each dentary bears 3 prominent molars; the anterior small, the middle larger and round, the posterior shoe-shaped. In the large dugong skeleton, the socket of the first molar is $4.7 \mathrm{~cm}$ deep and $1.6 \mathrm{~cm}$ wide, that of the second $4.7 \mathrm{~cm}$ deep and $2.2 \mathrm{~cm}$ wide. The anterior portions of the dentaries are deflected downwards, and are flattened to support the horny pad on the lower jaw.

Below the horny pad are 4 cavities on the right side and 5 on the left side (in the larger skuli) for lodging the rudimentary lower incisors. The pair at the anterior tip of the lower jaw is widely separated from the posterior pair. Only one pair of rudimentary incisors is present in the second pair of cavities. The anterior end of the right incisor was visible from the side. The anterolateral side of the lower jaw bears a foramen which is connected to a groove anteriorly. There are two such grooves on the right side. The foramen proper ends internal$1 y$ at the base of the posterior molar.

\section{Pectoral girdle}

The scapula is a large curved bone, broad on top and narrow below. The glenoid cavity is large. The spine is situated at about mid-length, and the acromion process is directed downwards. The cora-
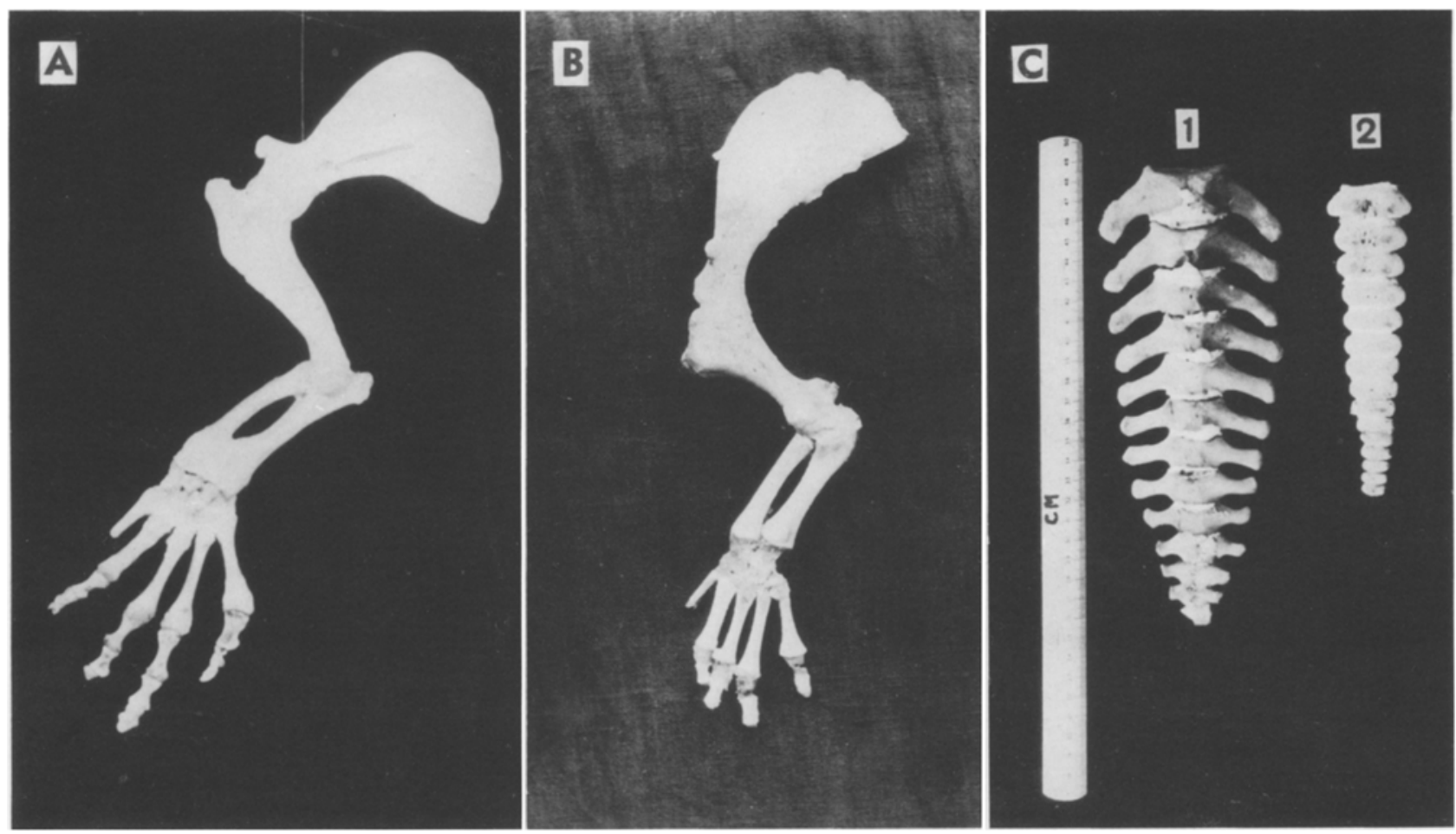

Fig. 3. Dugong dugon. Fore limb with pectoral girdle of (A) adult male, Posteriormost vertebrae of adult male (1) and juvenile female (2), dorsal views 
coid is curved and points downwards. The clavicles are absent (Fig. 3).

\section{Fore-Limb}

The humerus is a strong, irregularly curved bone, broad and flat on top and narrow below. At the upper end of the humerus there are 4 processes or tuberosities on the external side and two - including the head of the humerus - on the internal side. At the lower end there is only 1 internal process. The radius and ulna are united at their extremities; they gently curve to form a long, narrow passage between them. The articular surface is contributed more by the radius than the ulna, which extends beyond the upper part of the radius and covers the lower part of the humerus. The united portion of radius and ulna is narrow on top and broad below, the latter part providing articulation for two of the carpal bones.

The carpal bones are 3 in number -2 proximal, 1 distal to radius and ulna. The distal carpal articulates with the 2 proximal ones. The external proximal carpal (directly opposite to the ulna) has a process extending downwards, the posterior surface of which provides articulation for the fifth digit. The distal carpal bone provides articulation for the first 4 digits.

There are 5 digits, the metacarpals and phalanges of which are connected by well-formed joints (Fig. 3). The first digit is a single curved bone (Metacarpal I), broad proximally and narrow distal1y. While articulating with the carpal bone, a portion of its top on the external side provides an articular surface for the second metacarpal. The second digit consists of 1 rod-like metacarpal and 3 flattened phalanges, the metacarpal being the longest and the phalanges progressively decreasing in length distally. The third digit articulates partly with the distal carpal bone and partly with the upper end of the metacarpal of the second digit. A small, narrow gap exists within the articular facet of the second metacarpal and the carpal bone, and a wider gap between the articular facets of the second and third metacarpals. The third digit consists of 1 metacarpal and 3 phalanges, and is longer than the second - all its phalanges and metacarpals being longer. The fourth digit is the longest of the series, consisting of 1 metacarpal and 3 phalanges. The metacarpal is narrow proximally, broad and compressed distally. Its proximal end is narrower and its distal end broader than the corresponding portions of metacarpals of the preceding two digits. In general, the phalanges of the fourth digit are more compressed than all preceding ones. The fifth digit consists of 1 metacarpal and 3 phalanges and articulates with the facet provided by the proximal external carpal bone. The proximal portion of the metacarpal bears a small articular facet on the inner side which articulates with the top of the metacarpal of the fourth digit. The phalanges of the fifth digit curve inwards, the whole digit thus describing an inward bend. They are more com- pressed than those of the preceding digit. The proximal and distal ends of the metacarpal are broader than those of the corresponding segments of the preceding digits.

Except in the case of the first and fifth digits, the metacarpal of the other digits bears articulating surfaces on either side of its proximal end for articulation with its neighbours. The last phalanx (in some cases, the penultimate also) of all digits is irregular in shape.

\section{Sternum}

The sternum consists of a single piece of bone, with a short anterior median process (presternum) and a long posteromedian process (xiphisternum) which is bifurcated at the tip. The middle portion of the sternum is flattened, giving rise to 5 pairs of cartilaginous ribs.

\section{Pelvis}

The pelvis is rudimentary, represented by an elongate, curved bone on each side, narrow on top and broad below. The bone is attached on each side below the tips of the transverse processes of the 30 th vertebra, in an inclined position.

Hind 1 imbs are altogether absent.

\section{Vertebra1 Column}

The vertebral colum consists of 57 acoelous vertebrae divisible into 4 regions, i.e., the cervical containing 7 , the dorsal (thoracic) 18, the lumbar 6 , and the caudal 26 (Fig. 4). A clear demarkation between the last two regions is, however, difficult. The number of lumbar vertebrae for the dugong is generally fixed at 3 (Petit, 1955).

The first or "atlas" vertebra has 2 bean-shaped lateral facets anteriorly for articulation with the occipital condyles. Posteriorly, it has 2 lateral bean-shaped facets and a median basal, oval facet articulating with 3 similar facets on the anterior side of the second vertebra (axis). The odontoid process of the axis is prominent, resting on the central portion of the base of the atlas. Posteriorly, it shows 2 lateral spinous projections directed outwards. The posterior articular facet of the axis is large. There is only a slight indication of transverse processes on the 3 rd vertebra. Its neural arch has 2 elevated facets laterally for articulation with the upper spinous projections of the 2 nd vertebra. The second pair of projections of the second vertebra do not articulate with the 3 rd vertebra. Above the transverse process of the 3 rd vertebra, a complete foramen (costotransverse foramen) is formed on the right side, but is incomplete on the left side. The neural arch of the 3 rd vertebra is not complete$1 y$ fused on top, while that of the 2nd is completely fused. Above the transverse processes of the 4 th vertebra the foramina are complete on either 
side, the neural arch being incomplete. The 2 pairs of posterior processes visible on the 2nd vertebra are prominent on the $3 \mathrm{rd}$ also; on the $4 \mathrm{th}$, only the upper pair is prominent, the lower pair contributing to the foramina with the transverse processes. The neural arch of the 5 th vertebra is complete, and the transverse processes bear 2 downwardly directed processes. These processes are not prominent on the $6 \mathrm{th}$ vertebra. The $3 \mathrm{rd}, 4 \mathrm{th}$, and 5 th cervical vertebrae bear the costotransverse foramina. The neural arch of the 6 th vertebra is complete, its dorsomedian joint being distinct. No foramina are visible above the transverse processes of the 6 th vertebra. The 7 th vertebra is similar to the $6 \mathrm{th}$, but with a completely fused neural arch and 2 additional posterior ventrolateral facets for articulation with the first rib, in conjunction with 2 similar half facets on the anterior side of the 8 th vertebra.

The dorsal level of the second vertebra is higher than that of the first, but that of the successive vertebrae up to the 7 th gradually decreases as one vertebra fits below the other. Although the 8 th vertebra also fits below the 7 th, the neural arch is fairly raised compared to those in front of it. From the 9 th vertebra onwards the articular facets between 2 vertebrae are more or less parallel on either side. From this vertebra onwards, 2 prominent posterior projections (postzygapophyses) fit into concavities in a similar position on the next vertebra. From the 13 th vertebra, the postzygapophyses of the preceding and succeeding vertebrae providing articulation on either side become more acute. From the $31 \mathrm{st}$ vertebra onwards, the postzygapophyses are completely absent, whereas the prezygapophyses are prominent and are directed upwards. However, there is a slight indication of the postzygapophyses on the left side of the $32 \mathrm{nd}$ vertebra. This difference in the prominence of pre- and postzygapophyses also corresponds to the division of the vertebral column, i.e., the precaudal and postcaudal divisions. The prezygapophyses are distinct up to the 40 th vertebra, from whence they gradually merge with the centrum up to the 46 th vertebra, beyond which there is no trace of them.

The chevron bones are well developed, typical in structure and are distinct from the 32 nd to the 41 st vertebra. They articulate between two successive vertebrae.

The centra of the cervical vertebrae are characteristically thin and plate-like. From the 8 th vertebra onwards they are thick and circular up to the 44 th vertebra. They are triangular in section from the 45 th to the 50 th vertebra. The rest of the centra are dorsoventrally flattened
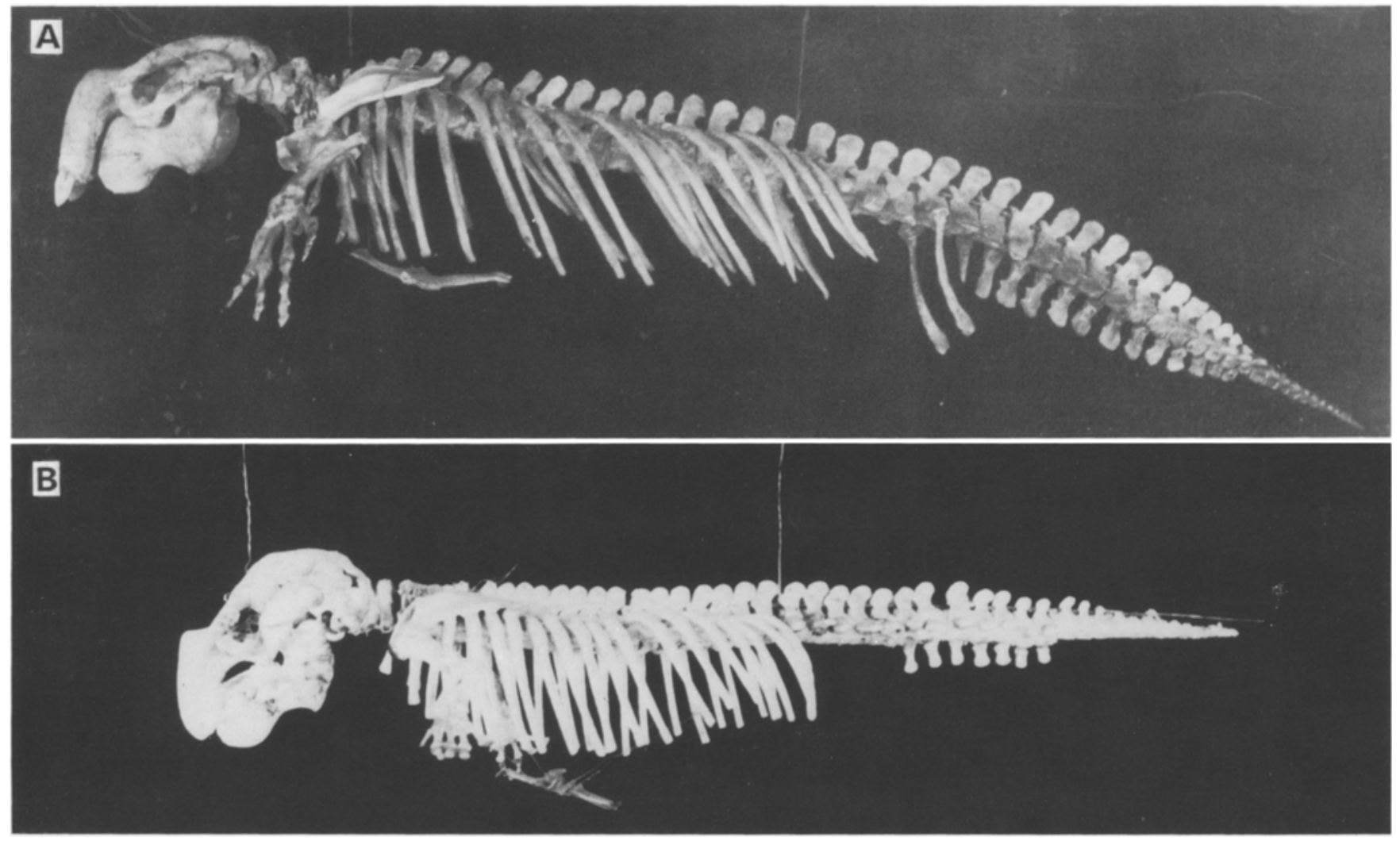

Fig. 4. Dugong dugon. Lateral view of complete skelton of (A) adult male, (B) juvenile female 
(Fig. 3C). The centra of almost all vertebrae from the 8 th onwards show ventrolateral concavities. Throughout the vertebral column, between two centra, an intervertebral disc is present to facilitate the bending of the vertebral column.

The neural spine is prominent from the 8 th to the 44 th vertebra. Complete neural arches are present from the 8 th to the 47 th vertebra. However, rudiments of the neural arch are also visible in the $48 \mathrm{th}$ and the $49 \mathrm{th}$ vertebrae. The first com plete haemal arch is found on the 32nd vertebra, which marks the beginning of the caudal vertebrae. There is no trace of a haemal arch from the 45 th to the 47 th vertebra.

The transverse processes are prominent from the 26 th to the 53 rd vertebra. The last 4 vertebrae also bear them, but appear as mere lateral extensions only (Fig. 3C). The transverse processes of the 40th to 53rd vertebra are rod-like with truncate tips, while in front of the 40 th vertebra they are dorsoventrally flattened with blade-like tips. The tips of the transverse processes of the 26 th and 27 th vertebra are joined latera11y.

\section{Ribs}

The thoracic vertebrae ( 8 th to $25 \mathrm{th}$ ) bear the 18 pairs of ribs. Vertebrae 7 to 14 have double joints for ribs, and the remaining vertebrae only single joints. In the former case, the capitulum of the rib articulates with two successive centra and its tuberculum articulates with the transverse process of the corresponding vertebra only.

The first rib is more or less straight and cylindrical; from the second onwards, the ribs are curved - the 2 nd to 4 th ribs are compressed while the rest are cylindrical. The tips of the anterior 12 pairs of ribs are truncate, those of the last 6 pairs pointed. From the 5 th rib onwards, a protuberance is present at about the mid-length of the rib. These protuberances, which are directed backwards, are more conspicuous on the $14 \mathrm{th}, 15 \mathrm{th}$, and $18 \mathrm{th}$ pairs of ribs.

\section{Teeth}

The upper incisors (tusks) project prominently in the male, but are scarcely visible outside in the female. Their bases, which are outcurved, are located at the top of premaxillaries. In the skull of the adult male (condylobasal length, $354 \mathrm{~mm}$ ) and also in all the other large skulls (condylobasal length, 262 to $384 \mathrm{~mm}$ ), there is 1 socket on each side of the skul1; in the smallest skull (condylobasal length, $153 \mathrm{~mm}$ ), 1 pair is visible on each side (Fig. 2). In all the skulls, the lower incisors are rudimentary, and are covered by the horny plate. In the majority of skulls, even the abortive teeth are not visible and the cavities are filled up by bony lamellae. In one of the skulis, one pair of lower incisors was found which are rod-1ike and curved anteroventrally.

A maximum of 3 molars are present on each side in both jaws. The first 2 are usually small, the last (both upper and lower) elongate and shoeshaped in some specimens. The molars have no roots nor enamel, and possess tuberculated crowns which wear down to flat surfaces. While most of the molars (the portions lying in the sockets) are curved outwards, a few may be curved backwards and others may be straight. The dental formula may be written as

$$
\text { i } \frac{1-2}{4-5} m \frac{3}{3} \text {. }
$$

The variation in the number of teeth in the skulls examined is given in Table 1.

Comparison of the Adult with the Young Skeleton

Detailed examination of the skeleton of the young juvenile female (106 cm long) revealed several interesting differences from that of the adult $(274 \mathrm{~cm}$ ) described above (Table 2).

To study the change, if any, in the angle of deflection of premaxillaries with growth, the angle of deflection of premaxillaries was plotted against the condylobasal length of the sku11. It is evident from the scatter diagram that the angle is greater in the young dugong than in the adult.

\section{Statistical Analyses of Skull Measurements}

In order to study the relationship between the condylobasal length of the skull and body length in Dugong dugon, the condylobasal lengths of the two skulis for each of which the corresponding length of the body is known were plotted against each other. The condylobasal lengths of all the other skulls, were also plotted; all formed a straight line with the first two points (Fig. 5), indicating that the relationship is simple and direct. This relationship may be useful to determine the length of the body if the condylobasal length of the sku11 is known and vice-versa. Lack of more data, however, make determination of the exact mathematical relationship impossible.

of the 14 morphometric measurements made for the skulls, the following 8 were statistically

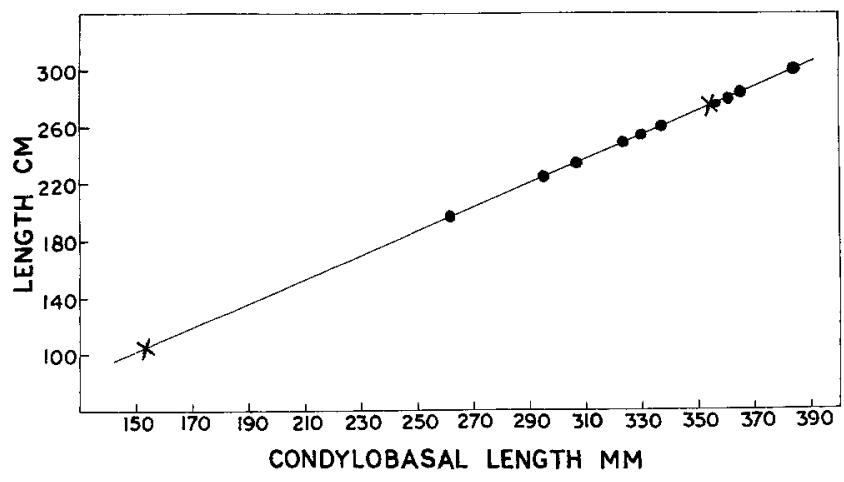

Fig. 5. Dugong dugon. Relationship between condylobasal length of skull and body length. $x$ : Points drawn from exact measurements of both parameters 
Table 2. Dugong dugon. Differences in skeletal features between adult male and juvenile female

\begin{tabular}{|c|c|c|}
\hline \multirow{2}{*}{ Character } & \multicolumn{2}{|l|}{ Description } \\
\hline & Adult male & Juvenile female \\
\hline \multicolumn{3}{|l|}{ Sku11 } \\
\hline Neurocranium & Heavy, elongate & Light, round \\
\hline Suture between frontals & Not clear & Clear \\
\hline Suture between parietals & Not clear & Visible as wavy line \\
\hline $\begin{array}{l}\text { Articulation of exoccipitals } \\
\text { with supraoccipital }\end{array}$ & Direct & $\begin{array}{l}\text { Through intervening } \\
\text { cartilage }\end{array}$ \\
\hline Occipital condyles & $\begin{array}{l}\text { Relation with } \\
\text { exoccipitals } \\
\text { not evident }\end{array}$ & $\begin{array}{l}\text { Relation with } \\
\text { exoccipitals evident }\end{array}$ \\
\hline $\begin{array}{l}\text { Rostrum (deflected part } \\
\text { of premaxillaries) }\end{array}$ & Uniformly thick & $\begin{array}{l}\text { Broad at both ends, narrow in } \\
\text { middle. Beak-like, with lateral } \\
\text { concavities in front half }\end{array}$ \\
\hline $\begin{array}{l}\text { Articulation between basis- } \\
\text { phenoid and exoccipitals }\end{array}$ & $\begin{array}{l}\text { Masked by occipi- } \\
\text { tal condyles }\end{array}$ & Joint is distinct \\
\hline $\begin{array}{l}\text { Suture between basis- } \\
\text { phenoid and vomer }\end{array}$ & Indistinct & Distinct \\
\hline $\begin{array}{l}\text { Posterior end of jugal where } \\
\text { it articulates with squamosal }\end{array}$ & $\begin{array}{l}\text { Rod-1ike, extend- } \\
\text { ing below anterior } \\
\text { end of squamosal }\end{array}$ & $\begin{array}{l}\text { Truncate, juxtaposed to } \\
\text { anterior end of squamosal }\end{array}$ \\
\hline $\begin{array}{l}\text { Number of sockets for } \\
\text { incisors in premaxillary } \\
\text { (1 side) }\end{array}$ & One & Two \\
\hline Vertebral Column & $\begin{array}{l}\text { Distinct, well } \\
\text { developed }\end{array}$ & $\begin{array}{l}\text { Small, not elevated to same } \\
\text { level as jugal and frontal, } \\
\text { hence located in a depression }\end{array}$ \\
\hline $\begin{array}{l}\text { Neural arches of first } 2 \\
\text { vertebrae }\end{array}$ & Complete & Incomplete \\
\hline $\begin{array}{l}\text { Lateral foramina in } 3 \text { rd to } \\
5 \text { th cervical vertebrae } \\
\text { (costotransverse foramina) }\end{array}$ & Present & Absent \\
\hline Total number of vertebrae & 57 & 53 (possibly a few lost) \\
\hline Posteriormost vertebrae & Depressed & Compressed anteroposteriorly \\
\hline $\begin{array}{l}\text { Nature of centra of } \\
\text { vertebrae }\end{array}$ & $\begin{array}{l}\text { Hard and non- } \\
\text { porous }\end{array}$ & Soft and porous \\
\hline $\begin{array}{l}\text { Projections on posterior } \\
\text { margins of ribs }\end{array}$ & Conspicuous & Inconspicuous \\
\hline Articular facets for ribs & Distinct & Indistinct \\
\hline $\begin{array}{l}\text { Posteriormost vertebra with } \\
\text { closed neural arch }\end{array}$ & $47 t h$ & $40 t h$ \\
\hline $\begin{array}{l}\text { Fore limb } \\
\text { Ankylosis of radius and } \\
\text { ulna at their extremities }\end{array}$ & Complete & Incomplete \\
\hline Ossification of carpals & Complete & Incomplete \\
\hline \multicolumn{3}{|l|}{ Sternum } \\
\hline Structure & $\begin{array}{l}\text { Consists of } \\
\text { single piece }\end{array}$ & $\begin{array}{l}\text { Consists of } 2 \text { pieces, pre- } \\
\text { and xiphisternum connected } \\
\text { by cartilage }\end{array}$ \\
\hline
\end{tabular}


dugong from the Indian region (Table 3); regression lines are shown in Fig. 6. Similar studies on metrical and non-metrical variation in the skulls of Gir lions have been presented by Todd (1965).

\section{Discussion}

Gohar (1957), on the basis of certain morphological and anatomical characters, mentioned below, considered the Red Sea dugong as forming a distinct subspecies called Dugong dugong tabemaculi. Bertram and Bertram (1966), after extensive investigations in Australia and adjacent areas with a view to collecting first-hand knowledge on the present taxonomic status of the dugong, opined that it may be divisible into an eastern and into a western species or variety.

According to Gohar (1957), the Red Sea dugong differs from the Indo-Australian dugong in maximum size attained, size at birth, relative development of mammae in the sexes, development of teeth, certain osteological characters, and other anatomical features. Since a detailed osteological study of the dugong from the Indian region has now been made, it is possible to compare its characteristics with those of the Red Sea dugong (Table 4).

From Table 4, it may be seen that the Red Sea dugong resembles that from India in most ways. However, some differences are apparent in Characters $1,2,9$, and 10 which may be related to size (age) of the specimens examined. For example, in the specimens from India, the adult and juvenile display some interesting differences in certain skeletal features (ankylosis of radius and ulna, structure of sternum etc., Table 2) between each other which are due to difference in the age of the individuals. It may also be mentioned that the 3 skulls from specimens presumably from the Arabian Sea examined in this study also showed no differences from those from the Gulf of Mannar and Palk Bay.

In addition to the above similarities, the maximum size attained (so far only adults under 300 $\mathrm{cm}$ observed) and the size at birth (one $106 \mathrm{~cm}$ young specimen had well developed molars and was feeding independently as evidenced by the presence of gut contents) of the dugong from the Indian region compare very well with those reported for the Red Sea dugong (adult not exceeding $315 \mathrm{~cm}$ and young less than $100 \mathrm{~cm}$ at birth). Further anatomical comparison of the dugongs of the two regions could lead to the conclusion that the Red Sea dugong and the dugong from the Indian region belong to the same species, being separated only geographically. Those differences which are apparent do not seem to be so great as to justify their classification as distinct subspecies. Although Petit (1955) felt that a species which is widely distributed should constitute sub-species or geographic races, he commented that, among the dugongs, individual variations are so great and the number of specimens examined in each country so sparse that it is not possible to define the

Table 4. Dugong dugon. Comparison of osteological characters of Red Sea dugong with those of dugong from India

\begin{tabular}{|c|c|c|c|}
\hline \multicolumn{2}{|c|}{ Character } & \multirow{3}{*}{$\begin{array}{l}\text { Red Sea dugong } \\
\text { Strong, heavy and broad } \\
\text { Distinct1y convex }\end{array}$} & \multirow{3}{*}{$\begin{array}{l}\text { Indian dugong } \\
\text { Strong, heavy and narrow } \\
\text { S1ightly convex }\end{array}$} \\
\hline 1 & Skul1 & & \\
\hline 2 & Roof of cranium & & \\
\hline 3 & Zygomatic arch & Strong & Strong \\
\hline 4 & Premaxillaries & Broad and stout & Broad and stout \\
\hline 5 & $\begin{array}{l}\text { Angle of deflection } \\
\text { of premaxillaries }\end{array}$ & $\begin{array}{l}\text { Less prominent (actual angle } \\
\text { not given) }\end{array}$ & Varies from $120^{\circ}$ to $136^{\circ}$ \\
\hline 6 & $\begin{array}{l}\text { Abortive teeth in } \\
\text { lower jaw }\end{array}$ & Rare, only one case reported & $\begin{array}{l}\text { Rare, actually seen in } \\
\text { one case so far }\end{array}$ \\
\hline 7 & $\begin{array}{l}\text { Deciduous incisor } \\
\text { tusk }\end{array}$ & $\begin{array}{l}\text { Never attains a large size, } \\
\text { does not co-exist with } \\
\text { permanent tusk }\end{array}$ & $\begin{array}{l}\text { Does not co-exist with } \\
\text { permanent tusk }\end{array}$ \\
\hline 8 & $\begin{array}{l}\text { Number of sockets in } \\
\text { symphysial part }\end{array}$ & $\begin{array}{l}\text { Almost } 1 / 3 \text { of specimens } \\
\text { have } 4 \text { on one side, } 5 \text { on } \\
\text { other side }\end{array}$ & $\begin{array}{l}1 \text { out of } 7 \text { examined, had } \\
4 \text { on one side, } 5 \text { on other } \\
\text { side }\end{array}$ \\
\hline 9 & Pelvic bones & Weak and slender & Strong \\
\hline 10 & Radius and ulna & $\begin{array}{l}\text { Free, fusion restricted to } \\
\text { thick cartilaginous pad on } \\
\text { surface, articulating with } \\
\text { humerus }\end{array}$ & Fused together at heads \\
\hline
\end{tabular}


subspecies and their distribution area. According to Petit, the dugong form from the Red Sea is synonymous with the Indian form, and the differences between the Red Sea dugong and the Australian dugong may be greater than those between the Red Sea and Indian dugongs.

Therefore, before any definition of the subspecies of the dugong can be attempted, comparable data must be available on the various morphological, anatomical, and biological aspects from representative localities within the vast distribution area of the species: east from the Solomon Islands, west to the Gulfs of Suez and Aquaba (Bertram and Bertram, 1966). It is hoped that the information presented in this paper will be of use in such comparisons.

Acknowledgements. I am grateful to Dr. S. Jones, former Director, Central Marine Fisheries Research Institute, Cochin for his keen interest in this work and for providing facilities to carry out the same. I am also grateful to Dr. N.K. Panikkar, Member, National Comission on Agriculture, New Delhi for going through the manuscript and offering advice.

\section{Literature Cited}

Beddard, F.: The Cambridge natural history. In: Mammalia, Vol. 10. pp 333-338. Ed. by S.F. Harmer and A.E. Shipley. London: Macmillan \& Co. Ltd. 1902. (Reprint Edition, 1968)

Bertram, K. and C. Bertram: Sea cows could be useful. Sea Front. I2, 210-217 (1966)
Gohar, H.A.F.: The Red Sea dugong, Dugong dugon (Erx1b.) subsp. tabemaculi (Ruppe11). Pub1s mar. biol. Stn Ghardaq̨a 9, 3-50 (1957)

Jones, S.: On a pair of captive dugongs (Dugong dugon) (Erxleben). J. mar. biol. Ass. India 1, 198-202 (1959)

- The dugong or sea cow - its present status in the seas around India with observations on its behaviour in captivity. Int. Zoo. Yb. 7, 215$219(1967)$

Mani, S.B.: Occurrence of the sea cow, Halicore dugong (Erxl.) off the Saurashtra coast. J. Bombay nat. Hist. Soc. 57, 216-217 (1960)

Mohan, R.S.L.: On the occurrence of Dugong dugon (Miller) in the Gulf of Kutch. J. mar. biol. Ass. India 5, p. 152 (1963)

Parker, T.J. and W.A. Haswe11: A text book of zoology, Vo1. 2. 952 pp. London: Macmillan \& Co. Ltd. 1940

Petit, G.: Ordre des sireniens. Sirenia Illiger, 1811. Traité Zool. 17, 918-993 (1955)

Sedgwick, A.: A student's text book of zoology, Vo1. 2. $705 \mathrm{pp}$. London: George Allen \& Unwin 1905

Silas, E.G.: Occurrence of the sea cow, Halicore dugong (Erxl.) off the Saurashtra Coast. J. Bombay nat. Hist. Soc. 58, 263-266 (1961)

Todd, N.B.: Metrical and non-metrical variation in the skulls of Gir lions. J. Bombay nat. Hist. Soc. 62, 507-520 (1965)

Date of final manuscript acceptance: June 5, 1974. Communicated by N.K. Panikkar, New Delhi 